Vol 1, No. 2, October 2021, Page. 13 - 18

Email : editorijhess@gmail.com

\title{
Utilizing Whatsapp As A Medium Of Learning Activities Biology In The Pandemic Covid-19
}

\author{
Nurlaily Chalizah. J ${ }^{1)}$, Tebawati Munthe ${ }^{* 2)}$, Ade Irwansyah Putra Nasution',
}

1,2,3) Fakultas Keguruan dan Ilmu Pendidikan, Universitas Islam Labuhan Batu, Rantauprapat

*Corresponding author

Email: lizachaniago36@gmail.com.

\begin{abstract}
This study aims to describe the: (1) the Utilization of WhatsApp as a learning medium in the tissues of the pandemic of Covid-19 in class XI IPA SMA Negeri 1 Kecamatan Na.IX-X Kabupaten Labuhanbatu Utara (2) Obstacles that occur in the use of WhatsApp as a learning medium in the tissues of the pandemic of Covid-19 in class XI IPA SMA Negeri 1 Kecamatan Na.IX-X Kabupaten Labuhanbatu Utara (3) the Solution is to overcome the barriers in the use of WhatsApp as a learning medium in the tissues of the pandemic of Covid-19 in class XI IPA SMA Negeri 1 Kecamatan Na.IX-X Kabupaten Labuhanbatu Utara. This research was conducted in SMA Negeri 1 Kecamatan Na.IX-X North Labuhanbatu District in the July to September 2021. This type of research is qualitative descriptive type of research phenomenology that describes about the use of WhatsApp as a learning medium in the tissues of the pandemic Covid-19. Data from this study were obtained through an interview with the Guardian class which became the main source of this research, then interviews with 5 students of class XI IPA-A, observation form observation passive participation and documentation as supporting data from the results of the interview. The results of the research showed that the teachers have been utilizing WhatsApp as a learning media to support the learning activities in the network (Online) by utilizing the various features available such as features photos, videos, documents and video call. Then in the implementation of the utilization of WhatsApp as a medium of learning there are several obstacles, namely the interference Signal, the memory of the Mobile phone is full, the Lack of Interaction, it is difficult to know the seriousness of the learners, the lack of learning motivation of learners, supporting facilities for online learning, and it is difficult to understand the material given, as well as in this study decrypt the solution is to overcome the obstacles that occur from the use of whatsApp as a learning medium in the tissues of the pandemic Covid19. From the results of this study it is suggested that educators are able to make learning variations, especially using the features of yag there on whatsApp, master and use of ICT in the learning process in the network (Online).
\end{abstract}

Keywords: WhatsApp, Learning Media, Learning in the Network

\section{INTRODUCTION}

Indonesia became one of the countries affected by the pandemic Covid-19. As terlansir in the news Kompas.Com., President Joko Widodo announced the first case of Covid-19 in the Presidential Palace March 2, 2020. Since from then until March 26, 2021, the Ministry of Health of the Republic of Indonesia data reveal that as many as 188.571 people infected by the Covid-19 (Ihsamuddin, 2020). The presence of the pandemic of Covid-19 in Indonesia is very impactful to the world of education. Melikat condition of Indonesia which failed to improve, then one way for am education is by way of distance education. Technology becomes a means of liaison between the teacher and the students. No learning face to face in school. All learning is directed online. According To O.Sullivan (2020) revealed that the outbreak of Covid-19 that attack the world at this time have an impact on the education sector. Teachers have to teach from home and students should learn from home. All academics within the scope of education should be searching for a method and the right strategies to revive education in the pandemic Covid-19. In addition to formal education affected by Covid-19, the learning activities also feel 
the same impact. The only way that the learning activities continue to run is to utilize technology as a means of connecting. As according to Dahwana (2020) revealed that the presence of distance learning or known as online learning can develop the skills of teachers in the teaching and learning process. It is that they want to researchers adoption to be an assumption of thinking in the search for the right solution to achieve the learning activities of biology in the pandemic Covid-19.

Learning is a process where a teacher providing guidance, assistance and direction to the students to have skills in learning. In addition to learning, should be good interaction between students and teachers. With the learning that is planned, there will be a learning process that is set in such a way to produce the expected value with the good. However, starting from March 2020 the world health organization (WHO) sets the Corona Virus Disease (Covid-19) as a pandemic that has struck more than 200 countries in the world. As a step to anticipate the spread of Covid-19 the government of Indonesia to perform some action, ranging from activities in the home course. Through these policies, the government wants the public to remain at home, work and worship in the home. These conditions gave a direct impact on the world of education.

The minister of Education and Culture (Mendikbud) Nadiem Anwar Makarim revealed, the emerging strategy of learning from home as a step to the first strategy the government in efforts to prevent the spread of Corona Virus Desiase (Covid-19) widely. The health and safety of the employees of the education to be a priority of the government. He also said that the users of the technology can be applied when doing distance learning. So that the learning process can still be implemented with appropriate expectations. Teachers as teachers are required to do innovation in learning by utilizing the application yan has been provided by the government to the educational process. For example an House of Learning, Our Table, WeKiddo, up Google For Education. The government also provides a tool video conferencing available to all users of G-Suite and Google Classroom, to join classes and continue their learning remotely from home. Based on interviews the author did with the biology teacher in SMA Negeri 1 Kecamatan Na.IX-X Kabupaten Labuhanbatu Utara, moments before the entry of the outbreak of Covid-19 in Indonesia, learning face-to-face in the classroom teacher using the method of group discussions or lectures. For example, on the material of the human respiratory system, teachers are using learning model of lectures or group discussions involving students must present the results of the group discussion in front of the class. In addition, teachers also utilize the learning media in the form of props and Powerpoint that can help students receive learning that is expected to achieve the objectives of the learning process desirable.

Furthermore, after the change of system learning face to face in class be learning from umah method daing (online) in accordance with the regulation of Ministry of education about the prevention outbreak of Corona Virus (Covid-19) and SMA Negeri 1 Kecamatan Na.IX-X Kabupaten Labuhanbatu Utara follow the regulations of the government to implement the learning process at home online. See the fact that the teacher is required to prepare a learning method of the home that is expected to meet the Minimum Completeness Criteria (KKM) of students so that the learning objectives can be achieved in line with expectations. To know how the process of learning biology online in SMA Negeri 1 Kecamatan Na.IX-X Kabupaten Labuhanbatu Utara then the researcher conducted an interview with one of the biology teachers in SMA Negeri 1 Kecamatan Na.IX-X Kabupaten Labuhanbatu Utara, he said that in the midst of a pandemic now in the process of learning activities remains to be done although not directly face to face. This is where the role guruuntuk can use social media especially WhatsApp. This 
activity supports the application of learning in the era of the 4.0 technology, the technology which today can be accessed to get the information very easily and can be done anytime and anywhere with its internet network, and to find appropriate solutions to overcome the problems that occurs in the middle of learning the pandemic Covid-19. In connection with the phenomenon of the pandemic at this time, the use of media in distance learning with assisted network greatly assist the process of learning, one of which is the utilization of WhatsApp. The utilization of WhatsApp as a learning medium in the tissues of the pandemic Covid-19 this Need to be reviewed more deeply related to the implementation of various schools, one of which is in SMA Negeri 1 Kecamatan Na.IX-X Kabupaten Labuhanbatu Utara. Based on the background that has been stated, the researcher interested to conduct research with the title "Utilizing WhatsApp As a Medium of Learning Activities Biology in The Pandemic Covid$19 "$.

\section{RESEARCH METHODS}

\section{The place and Time of Research}

This study was conducted in SMA Negeri 1 Kecamatan Na. IX-X Kabupaten Labuhanbatu Utara. The time this study was conducted in the month of July up to September 2021.

\section{Population and Sample}

According to Sugiyono (2014), the population is a generalization region consisting of the objects/subjects that have certain qualities and characteristics set by researchers to be studied and then drawn conclusions. The population in this study is a biology teacher and all students of class XI SMA Negeri 1 Kecamatan Na.IX-X Kabupaten Labuhanbatu Utara, consisting of 4 classes.

According to Sugiyono (2014), the sample is part of the number and characteristics possessed by the population. Determination of the sample is done puspose sampling. The existence of the samples selected in accordance with the criteria required needs. The sample in this study consists of a biology teacher and the students of class XI IPA-A SMA Negeri 1 Kecamatan Na.IX-X Kabupaten Labuhanbatu Utara. In this study, the researchers will stop searching for information if the information required has been obtained and adequate or until the level is saturated.

\section{Design and Types of Research}

Design this study is a qualitative approach. According to Bogdan and Taylor (Moleong, 2017) the methodology of a qualitative research procedure that produces the data description in the form of an explanation, written or verbal, of the subject observed. A qualitative approach is used to describe the utilization of WhatsApp as a medium of learning biology in the pandemic of Covid-19 in class X SMA Negeri 1 Kecamatan Na.IX-X Kabupaten Labuhanbatu Utara.

The type of research used is phenomenology. According to Kuntarto \& Sugandi (2018) that a phenomenological approach to generate the data of the existing findings in the field a deep and meaningful that will later be described as a form of the results of this study, with this approach the researcher as to see and feel the reality of what happened. From the explanation it is already proved that the type of this research is based on a phenomenon.

\section{Research Instruments}

Instruments that researchers use in this study is a statement-a statement that is formed in the form of a questionnaire, which is then given to the object of research, namely the students that 
researchers select and sample in this study. In addition to the questionnaire above, researchers also use the instrument the interview by asking questions to the teacher of biology to obtain accurate information about utilizing WhatsApp as a medium of learning biology in the pandemic Covid-19.

Data Collection Techniques

Data collection techniques used in this research is observation, interview, and documentation.

1. Observation

Observation is a data collection technique that is used when the researcher wants to know the human behavior, work processes, natural phenomena, and used for a response that is not too large (Sugiyono, 2016). This study uses a type of observation passive participation. According to Sugiyono (2017) stated that the observation of passive participation, namely in this case the researchers came to view the state of the place observed and not get involved with the activities carried out.

In this study, researchers observed how the use of WhatsApp as a medium of learning in a network with a plunge directly the activities carried out by the speaker, joined in the Group WhatsApp observe how the process of learning takes place with the media WhatsApp, in order to optimize the observation process with the involvement of researchers, researchers were able to appreciate and feel directly what is perceived by the subject, so that the data obtained has a position that is certainly in accordance with the actual situation. In general observation aims to support the collection of data can be done immediately after the event or during the course of an event.

2. Interview

The interviews in this study in the form of interviews semi-structure. According to Sugiyono (2017) stated that the interview semi-structure implementation is free. Interview spring structure is used to obtain a more open, in which the activities of the interview informants were asked opinions, and ideas related to the problem.

In this study, interviews were conducted using interview guidelines. The purpose of the interviews of this research is to know in depth about the use of WhatsApp as a medium of learning the biology of the pandemic Covid-19. The speakers in this interview, namely Teachers and students of class XI IPA-A SMA Negeri 1 Kecamatan Na.IX-X Kabupaten Labuhanbatu Utara.

3. Documentation

According to Sugioyono (2016) documentation of the data used to complete the results of observation and interview to the results of observations and interviews can be believed to the truth with its documentation. In this study the documentation of the selected namely in the form of a video or recording of the interview, the screenshot of the use of WhatsApp as a medium of learning biology, and photographs that support to complete the research data such as the syllabus, RPP and others.

Data Analysis Techniques

Analysis techniques in qualitative research is done at the time of research already in the field. The data analysis technique is using the model of Miles and Huberman. The steps of data analysis based on the model of Miles and Huberman in (Sugiyono, 2016:), namely data reduction, data display, and conclution drawing/verification.

1. Data reduction.

Data reduction means to summarize, choosing subject matter, focus on the data that was researched and discard data that is not necessary. The stage of data reduction in this study include: 
1) Perform a preliminary study of SMA Negeri 1 Kecamatan Na.IX-X Kabupaten Labuhanbatu Utara, to determine the utilization of WhatsApp as a medium of learning biology in the pandemic Covid-19.

2) Set the subject of the research that will be used as informants.

3) Do the observations of the use of WhatsApp as a medium of learning biology in the pandemic Covid-19 which was held by the teacher of class XI IPA-A SMA Negeri 1 Kecamatan Na.IX-X Kabupaten Labuhanbatu Utara.

4) conducted in-depth interviews with the type of interview spring structure to find out is to use WhatsApp as a medium of learning biology, barriers to use WhatsApp as a medium of learning biology, and the solution is to overcome the obstacles in the use of WhatsApp as a medium of learning biology in the pandemic of Covid-19 in SMA Negeri 1 Kecamatan Na.IX-X Kabupaten Labuhanbatu Utara.

5) Record the results of the teacher interviews and pesetra didik SMA Negeri 1 Kecamatan Na.IX-X Kabupaten Labuhanbatu Utara.

2. Data display (presentation of Data)

Presentation of data in research is in the form of narrative text. The Data compiled in the form of a brief description for easy understanding the phenomena that occur and prepare actions to be taken next based on what has been understood.

3. Conclution drawing/verification (Conclusion and verification)

Conclusion and verification in this study is done by comparing the process to use WhatsApp as a medium of learning biology is derived from the observation and interviews of teachers and the peseta students about the use of WhatsApp as a medium of learning the biology of the pandemic of Covid-19 in SMA Negeri 1 Kecamatan Na.IX-X Kabupaten Labuhanbatu Utara.

The Results Of The Research

\section{RESULTS AND DISCUSSION}

Penenitian was conducted in SMA Negeri 1 Kecamatan Na.IX-X Kabupaten Labuhanbatu Utara. This research begins on the date of 12 October 2020 to 10 March 2020 by doing observation and interview techniques on the use of whatsApp as a learning medium in the tissues of the Covid-19 in class XI IPA-A SMA Negeri 1 Kecamatan Na.IX-X Kabupaten Labuhanbatu Utara. WhatsApp is the medium of information technology that is very popular today, especially its use in the world of education as a learning media in supporting the success of a learning activity in the network (Online) at this time. Service features of WhatsApp such as Group WhatsApp, telephone, Personal chat, Emoticons are often used by teachers, send messages, documents, photos, video, pdf. Thus learning will be more interesting and fun. A variety of features that can be accessed for free using the internet network.

The process of data retrieval is done at the time before the study and when the rese arch took place. This research was conducted by direct observation on the use of WhatsApp as a medium of learning. The purpose of this study is to determine how the use of WhatsApp as a learning medium in the tissues of the Covid-19 done by the teacher in the learning, the obstacles encountered and the solutions taken to conquer the barriers that exist.

Then conducted in-depth interviews with the teachers and also the interview with 5 people learners who are accompanied by supporting evidence. Documentation in the form of photos and screenshots of learning using whatsApp while the teacher was teaching to be used as supporting data in the data retrieval. The researchers conducted interviews to virtual namely assisted whatsApp app with video call, to the learners and also nonvirtual to the teacher of 
biology of class XI IPA-A Mother Atiah who became the main subject in this research is the teacher of biology of class XI IPA-A, this action is done to see the process of learning is done online at home and also to reduce the spread of the outbreak of Covid-19.

1. The utilization of WhatsApp as a learning medium in the tissues of the pandemic Covid -19 class XI IPA-A SMA Negeri 1 Kecamatan Na.IX-X Kabupaten Labuhanbatu Utara.

Based on the results of research conducted in the month of July to September 2021 in class XI IPA-A SMA Negeri 1 Kecamatan Na.IX-X Kabupaten Labuhanbatu Utara, by doing observation and interview researchers have described, and supported by documentation, it can be seen that teachers make use of WhatsApp as a medium of learning in the network to support the learning process at home in this case the teacher has to carry out the policies issued by the Minister Nadiem Anwar Makarim that issued the Circular No. 3 of the Year 2020 in the Educational unit through the Circular Letter of the Minister of education and culture Number 36962/MPK.A/HK/2020 about "Learning Online (In the Network) in order to prevent the spread of the Corona Virus Disease (COVID - 19). Policies issued by it, forcing teachers and learners to continue to perform the process of learning from home with the help of the media distance learning one of them is the use of whatsApp are used by teachers of biology class XI IPA-A SMA Negeri 1 Kecamatan Na.IX-X Kabupaten Labuhanbatu Utara, all aktiviitas learning accessible via WhatsApp good delivery material, information, discussion and evaluation of the activities carried out by utilizing features such as photos and documents.

Based on the results of observations and interviews conducted by the class teacher of biology class XI IPA-A SMA Negeri 1 Kecamatan Na.IX-X Kabupaten Labuhanbatu Utara in the use of learning media can help the process of delivering information from the material to be studied. Private (2017) that the media has become in learning activities, so that the learning process becomes more effective and efficient. In the state of the pandemic at this time, the use of learning media in the network certainly provide convenience to teachers and learners in the process of communication during online learning. There are a lot of technology digital application that can be used According to the Jumiatmoko (2016) WhatsApp is an internet-based application that allows users to communicate with the available features and is the most popular social media used in communication. WhatsApp is becoming the choice to used to be the main media in the learning process online at SMA Negeri 1 Kecamatan Na.IX-X Kabupaten Labuhanbatu Utara.

Based on the results of observation and interview as well as reinforced by the evidence documentation, features of whatsApp which is often utilized the teacher in the learning process that features photos, videos, documents, Group WhatsApp, and call (call). With the features provided to facilitate teachers in the learning process. According to Barhomi (2015) the benefits of the features displayed in the learning that is WhatsApp Messenger Group give the facilities collaborative learning and collaborative online between teachers and students or fellow students either at home or at school, a free app that is easy to use and can be used to share comments, posts, images, videos, sounds, and documents.

Based on the results of interviews of teachers use the photo as a result of the processing tasks to the learners, the teacher will give the command or task then learners will send you 
the final result of their duties in the form of a photo shared on the Group WhatsApp or through personal chat to the teacher concerned, and then the delivery of the material is presented using the features of the document, teachers can submit a variety of forms of documents such as word, PDF, or PPT, in the learning activities of teachers use this feature in the form of a PPT or pdf that contains teaching materials. While the use of video, the teacher utilizing the WhatsApp media to share video of learning as a support activity to learn, the video created will be sent on the Group WhatsApp class, all the form of photographs, documents and videos submitted which can donwload and stored by the learners, Group WhatsApp as a container facilitators delivering a message that is filled out by the teacher and the learners, as well as features of call according to the Miladiyah (2017) to make a voice call with other users such as teachers with the teacher or with learners directly.

2. Barriers and solutions in the utilization WahtsApp as a learning medium in the tissues of the pandemic covid -19 class XI SMA Negeri 1 Kecamatan Na.IX-X Kabupaten Labuhanbatu Utara.

Yensy (2020) stated that the obstacles in the use of whatsApp as a learning medium is signal interference and memory handpone full namely :

1. Signal interference

2. HP,memory full

3. Lack of interaction

4. It's hard to know the seriousness of the learners

5. The motivation of learners

6. Facilities to support online learning.

7. It is difficult to understand the material given

\section{CONCLUSION}

Based on the results of research and discussion on the above conclusions can be drawn as follows :

1. The utilization of WhatsApp As a Learning Medium in the Tissues of The Pandemic Covid-19 By Teacher of biology class XI IPA-A SMA Negeri 1 Kecamatan Na.IX-X Kabupaten Labuhanbatu Utara first utilization implemented by the class teacher in the learning activities that load event opener, core, and cover. Then the features are often used features photos, videos, documents, Group WhatsApp, and call (call) directly. Ease is felt by the presence of features of whatsApp and also very easy to use and can be used by various groups.

2. Barriers in the use of WhatsApp as a learning medium in the tissues of the Pandemic of Covid -19 in class XI IPA-A SMA Negeri 1 Kecamatan Na.IX-X Kabupaten Labuhanbatu Utara, namely the interference signal resulting in whatsApp will be difficult to access, another obstacle is the lack of effective learning process the teacher can not directly see the seriousness of the learners, the memory of the phone quickly filled with the incoming document, not all learners have the tools supporting online learning at this time, the reason of such harm less confidence against the phone given, the lack of interaction between 
teachers and learners, as well as learning using whatsApp are also less effective because not all students understand the task and the material given.

3. Solutions to overcome the barriers in the use of WhatsApp as a learning medium in the tissues of the Pandemic of Covid -19 in class XI IPA-A SMA Negeri 1 Kecamatan Na.IX$\mathrm{X}$ Kabupaten Labuhanbatu Utara done by the teacher is to minimize all the constraints better than disruption of the network by extending the delivery period of the task, making the material pambelajaran is simple and easy to understand, interact with do a video call or interaction once a week according to the schedule of exchange of book learning, innovations and other media such as google classroom or zoom meeting but did not leave the main role of the use of whatsApp.

\section{REFERENCES}

Adam \& Taufik. (2015). Pemanfaatan Media Pembelajaran Berbasis Teknologi Informasi Bagi Siswa Kelas X Sma Ananda Batam. CBIS Journal. Vol. 3(2). 78-90.

Afnibar dan Fajhriani. (2020). Pemanfaatan WhatsApp Sebagai Media Komunikasi Antara Dosen Dan Mahasiswa Dalam Menunjang Kegiatan Belajar (Studi Terhadap Mahasiswa Uin Imam Bonjol Padang. Jurnal Komunikasi dan Penyiaran Islam.Vol.11(1).70-83.

Anwar dan Riadi.(2017). Analisis Investigasi Forensik WhatsApp Messenger Smartphone Terhadap Wahtsapp Berbasis Web. Jurnal Ilmu Teknik elektro Kompuer Dan Informatika. Vol.3(1). 2-10.

Astini,S. (2020). Pemanfaatan Teknologi Informasi Dalam Pembelajaran Tingkat Sekolah Dasar Pada Masa Pandemi Covid-19. Jurnal Lampuhyang. Vol.11(2). 13-25.

Barhomi, Choki(2015) " e Eff ectiveness of WhatsApp Mobile Learning Activities Guided by Activity eory on Students " Knowledge Mangement" Contemporary Educational Technology, Vol 6 (3). 221-238.

Basori. (2013). Pemanfaatan Social Learning Network "Edmodo" dalam Membantu Perkuliahan Teori Bodi Otomotif di Prodi PTM JPTK FKIP UNS. JIPTEK, VI, 99- 105.

Daheri, dkk. (2020). Efektifitas WhatsApp sebagai Media Belajar Daring. Jurnal Basiced.Vol.4(4). 775-783.

Dewi, W. A. F. (2020). Dampak Covid-19 Terhadap Implementasi Pembelajaran Daring di Sekolah Dasar. Vol. 2(1). 7.

Firman \& Rahman. (2020). Pembelajaran Online Di Tengah Pandemi Covid-19. Indonesian Journal Of Educatoinal Science (IJES).Vol.2(2). 81-89.

Jumiatmoko. (2016). WhatsApp Messenger Dalam Tinjauan Manfaat Dan Adab. Wahana Akademika. Vol 3 (1). 52-66 
Vol 1, No. 2, October 2021, Page. 13 - 18

Email : editorijhess@gmail.com

Khoiroh, Nazmi. (2019). Penggunaan WhatsApp dalam pembelajaran pada mahasiswa pendidikan fisika.Jambi: Fakultas Keguruan Dan Ilmu Pendidikan Universitas Jambi.

Kuntarto, E. (2017). Keefektifan Model Pembelajaran Daring Dalam Perkuliahan Bahasa Indonesia Di Perguruan Tinggi. Journal Indonesian Language Education And Literature. Vol.3(1).99-110. 